\title{
Nitrogen and Phosphorus Salts Treatment Effect to Spot Blotch Development on Barley
}

\author{
Vladimir Zakharov ${ }^{1}$, Anton Sidorov², and Lev Tyryshkin² \\ ${ }^{1}$ Ulianovskii NIISKH, Russia \\ ${ }^{2}$ All-Russian Institute of Plant Genetic Resources, Russia
}

\section{Abstract}

The paper presents the data on seedling and adult resistance to dark-brown leaf spot blotch (Bipolaris sorokiniana) in barley samples described in modern literature as resistant to the disease and in varieties allowed growing in the territory of Russian Federation. All 32 samples and 69 varieties under study were highly susceptible to the blotch at both growth stages. This fact indicates to urgent need in developing new methodes for dark-brown leaf spot blotch protection. Treatment of barley plants varieties with mixture of nitrogen and phosphorus salts solution reduced the disease development on seedlings of 13 commercial varieties and on adult plants of 36

Corresponding Author:

Vladimir Zakharov

ulniish@mail.ru

Received: 25 October 2019

Accepted: 15 November 2019

Published: 25 November 2019

Publishing services provided by Knowledge E

(c) Vladimir Zakharov et al. This article is distributed under the terms of the

Attribution License, which

permits unrestricted use and redistribution provided that the original author and source are credited.

Selection and Peer-review under the responsibility of the AgroSMART 2019 Conference Committee.

\section{G OPEN ACCESS} varieties (52\% out of all studied). For all these 36 varieties weight of 1000 grains was significantly higher on treated plots compared to untreated ones for $11--108 \%$. The mechanism of nitrogen and phosphorus salts effect on the dark-brown leaf spot blotch development (changing virulence/aggressiveness of the pathogen) indicates that change of the salts concentrations and their ratio in the solution could expand the set of host plants genotypes on which this treatment will decrease the disease development.

Keywords: barley, spot blotch, nitrogen, phosphorus salts

\section{Introduction}

Dark-brown leaf spot blotch (causal agent Bipolaris sorokiniana Shoem.) is an extremely harmful leaf disease of barley, prevalent in all regions of the crop growing [1, 2]. The most economically profitable and ecologically safe method of protection from this disease, as well as other diseases is the cultivation of resistant varieties. In order to develop these varieties, it is necessary to search donors for resistance, i.e. the samples having effective genes for the trait, which can easily transfer it through hybridization. However, according to several researchers' viewpoint genetic diversity of cultivated barley for highly effective resistance to dark-brown leaf spot blotch is extremely narrow and a set of resistant genotypes is very limited [3--6]. Moreover, many previously identified sources of resistance have been shown to be susceptible to this disease. The World collection of the Institute of Plant Genetic Resources (VIR) plays an important role in the identification 
of new resistant genotypes. Recent years, a relatively large number of barley samples resistant to dark-brown leaf blotch were selected from this Collection or created on its bases [7--12]. The first purpose of the work was to study the resistance of these genotypes as well as of barley varieties allowed being grown in Russian Federation regions to this disease.

Earlier in our work, the reduction of dark-brown leaf spot blotch development on seedlings of some barley genotypes has been shown under the effect of nitrogen and phosphorus salts [13]. This decrease effect was proven to be the result of modification variation of the causal agent for virulence/aggressiveness under the influence of these chemical substances [13]. The second task of this work was to study the possibility of reducing the disease development on commercial barley varieties as a result of plant treatments with a mixture of nitrogen and phosphorus salts.

\section{Materials and Methods}

\subsection{Materials}

Plant materials were the samples of barley, described in recent scientific literature as resistant to dark- brown leaf spot blotch kk (catalogue numbers in VIR database) 15138, 23822, 30084 [7], Kristall 71, Bios 1, Zazerskii 85, Kimberley, Romantik, Diamond, Lizen, Balga, Nordic, Acha, ShortStraw, Chinook, Sviatogor, Novichok, Nur, Severianin, Leningradskii, Baltika, Aidas [11]; kk-11440, 11475, 12214, 14999, 15811, 16376, 15032 , 15037, Bagan, Nutans 553 [8]; and 67 varieties of spring barley from 4 countries (the Russian Federation, Belarus, Germany, France, Denmark), allowed being cultivated in the Russian Federation territory. (Abava, Abalak, Alei, Batik, Bat'ka, Belgorodskii, Bogatyr, Brennus, Brovar, Buian, Veles, Vladimir, Volgogradskii 08, Volgogradskii 12, Vorsinskii, Gonar, Grais, Despina, JB Flavour, Dmitrievskii 5, Eifel, Zhana, Zazerskiii 85, Zevs, Zenit, Zolotnik, Izumrud, Kalkiul, Kangoo, Kati, Kvench, Krasnoiarskii 91, Krasnoiaruzhskii 6, Krinichnyi, Leningradskii, Leon, Medikum 157, Miar, Mihailovskii, Moskovskii 3, Moskovskii 86, Niagara, Novik, Nur, Overtiug, Odissei, Olenek, Olimpik, Omskii 99, Oskoletc, Pamiati Rodinoi, Pamiati Chepeleva, Pioner, Salair, Sanshine, Sasha, Serbinetta, Solist, Sonet, Suzdaletc, Tausen, TSHA 4, Ceppelin, Cherio, Chill, Shchedryi, Eksploer, Elf, laromir). 


\subsection{Methods}

The evaluation of young resistance to dark-brown leaf spot blotch, seeds of studied samples were sown on water-wetted cotton rolls in cuvettes which after seeds germinated were placed in a light chamber $\left(20--22^{\circ} \mathrm{C}\right.$, constant illumination 2500 lux). Seedlings at stage of 1--2 leaves were placed in cuvettes horizontally and sprayed with suspension of highly aggressive strain T B. sorokiniana conidia (concentration 50 thousand spores $/ \mathrm{ml}$ suspension). Cuvettes with plants after inoculation were wrapped with polyethylene, left in darkness for 12 hours, and then again transferred to the light chamber.

Rating of dark-brown leaf spot blotch development was carried out 7 days after infection with the pathogen according to scale: 0 -- absence of symptoms; $1,2,3$, $4--10,20,30,40 \%$ of the diseased leaf surface, $5-50 \%$ or more of diseased of the leaf surface, 6 -- leaf death. The samples with disease rating 5--6 were rated as susceptible, 3--4 -- moderately resistant, 0--2 -- highly resistant [4, 14]. The seedling resistance evaluation for each sample was carried out in 3 independent experiments.

To study adult plants resistance, the seeds of studied samples and varieties were sown in the field of Pushkin Laboratories of VIR (North-West region of Russia) in 2018. Plants at the earlier heading stage were sprayed with suspension of $B$. sorokiniana conidia (concentration of 20 thousand spores $/ \mathrm{ml}$ suspension). To create a provocative condition, plants were covered with the material SpunBond. The disease development was scored one month after infection with index "percentage of the affected flag-leaves surface" [4, 15].

When studying the effect of treatment with mixture of nitrogen and phosphorus salts on the seedling infection by dark-brown leaf spot blotch, intact plants at 1-2 leaf stage, as well as $2 \mathrm{~cm}$ leaf segments placed on wetted cotton were sprayed with a solution of a mixture of ammonium nitrate (concentration of $\mathrm{NH}_{4} \mathrm{NO}_{3}$ was $2.57 \mathrm{~g} / \mathrm{L}, \mathrm{N}$ concentration -- $0.9 \mathrm{~g} / \mathrm{L})$ and one-substituted sodium phosphate dihydrate $\left(\mathrm{NH}_{2} \mathrm{PO}_{4} \times 2 \mathrm{H}_{2} \mathrm{O}\right.$ was 3.94 $\mathrm{g} / \mathrm{L}, \mathrm{P}_{2} \mathrm{O}_{5}$ concentration -- $1.8 \mathrm{~g} / \mathrm{L}$ ). The seedlings were dried out and infected by the disease causal agent as indicated above. The spot development was rated after 7 days according to the same scale.

Under field conditions, plants of barley varieties at heading stage were sprayed with solution of a mix of ammonium nitrate and one-substituted sodium phosphate three times with interval of 7 days (an overall dose $\mathrm{N}$-- $810 \mathrm{~g} / \mathrm{ha}$, dose $\mathrm{P}_{2} \mathrm{O}_{5}$ was $1620 \mathrm{~g} / \mathrm{ha}$ ). The dose of liquid at each treatment corresponded to $300 \mathrm{l} / \mathrm{ha}$. Immediately after the first treatment plants were sprayed with suspension of the causative agent of dark brown leaf spot blotch conidia ( 20 thousand spores/ml suspension). The development of the 
disease was rated 7 days after the last treatment with a mixture of salts according to the percentage of the affected surface of the flag-leaves. For each variety in the control (without treatment) and experiment groups (treatment with a mixture of nitrogen and phosphorus salts) 1000 grains weight was assessed after harvesting in 3 replications. Significance of differences between variants was determined by means of two-factor dispersion analysis (ANOVA) with use of LSD index.

\section{Results}

According to the results of 3 independent laboratory experiments all 32 studied samples described in the national literature as resistant to dark-brown leaf spot blotch were highly susceptible to the disease at the seedling stage (disease score 6). Similarly, all the 69 studied barley varieties recommended for cultivation in the territory of the Russian Federation were susceptible at this stage of ontogenesis to dark-brown leaf spot blotch.

As a result of artificial infection of plants in the field, a heavy infectious and provocative conditions were created: all samples and varieties, including those described in the literature as resistant to leaf spot blotch were very strongly affected by the disease (80--90 \% of the diseased surface of the flag-leaves).

For 13 barley varieties out of 69 studied significant decrease in dark-brown leaf spot blotch development, both on the leaf segments and on intact seedlings has been shown as a result of their treatment with a mixture of nitrogen and phosphorus salts (Table 1); $100 \%$ of the leaf surface was affected in the control, $10--30 \%$ in the experimental variant.

For other varieties, this treatment was ineffective in terms of reducing the development of leaf spot blotch (ratings 6 both in control and in experiment). This result is consistent with the data we have previously received about the genotype-specific effect of used chemicals on the disease development [13]. The main conclusion from this part of the work is that treatment with a mixture of nitrogen and phosphorus salts in given concentrations can significantly reduce the development of this extremely harmful disease on the seedlings of commercial barley varieties, but this reduction is evidently variety specific.

The treatment of barley plants under field conditions with mixture of nitrogen and phosphorus salts 3 times after infection with the parasite led to significant decrease in dark-brown leaf spot blotch development (from $90 \%$ to 5 --30 \%) on the flag-leaves of 36 varieties, presented in Table 2 . 
TABLE 1: Development of dark-brown leaf spot blotch (scores) on seedlings of barley varieties after treatment with solution of a mixture of ammonium nitrate and one-substituted sodium phosphate.

\begin{tabular}{l|c|c|c|c|}
\hline & \multicolumn{2}{c|}{ Intact plants } & \multicolumn{2}{c|}{ Leaf segments } \\
\hline Variety & Control & NP treatment & Control & NP treatment \\
\hline Abava & 6 & 2 & 6 & 2 \\
\hline Zenit & 6 & 3 & 6 & 2 \\
\hline Chill & 6 & 3 & 6 & 2 \\
\hline Despina & 6 & 1 & 6 & 2 \\
\hline Kalkiul & 6 & 2 & 6 & $1-3$ \\
\hline Abalak & 6 & 2 & 6 & 2 \\
\hline laromir & 6 & 2 & 6 & 2 \\
\hline Zhana & 6 & 1 & 6 & 1 \\
\hline Krasnoiaruzhskii 6 & 6 & 1 & 6 & 1 \\
\hline Cheerio & 5 & 1 & 6 & 2 \\
\hline Overtiug & 6 & 2 & 6 & 3 \\
\hline Krasnoiarskii 91 & 6 & 2 & 6 & 3 \\
\hline Volgogradskii 12 & 6 & 1 & 6 & 1 \\
\hline
\end{tabular}

Other varieties showed no visually detectable significant decrease in development of the disease after adult plant treatment with a mix of nitrogen and phosphorus salts at concentrations given in materials and methods. Taking into account the underlined mechanism of nitrogen and phosphorus salts effect on the dark-brown leaf spot blotch development (changing virulence/aggressiveness of the pathogen) [13] we can propose that change of the salts concentrations and their ratio in the solution could expand the set of host plants genotypes on which this treatment will significantly decrease the disease development.

For all 36 varieties, at which significant decrease in spot blotch development under field condition was recorded, weight of 1000 grains was higher on treated plots compared with untreated ones for 11--108 \% (table 2). We suppose that this increase of one productivity index is related to the decrease of dark-brown leaf spot blotch development but not to salts treatment influence directly to plants. First, the concentrations of salts were extremely low $\left(\mathrm{NH}_{4} \mathrm{NO}_{3}\right.$ is $2.57 \mathrm{~g} / \mathrm{L}, \mathrm{NH}_{2} \mathrm{PO}_{4}$ is $3.94 \mathrm{~g} / \mathrm{L}$ in solution, the total dose for 3 treatments per hectare -- 2.31 and $3.55 \mathrm{~kg}$ respectively) to increase crop yields significantly and, secondly, for those varieties that did not show decrease in the disease development, the weight of the seeds in control and experiment did not differ significantly (data not shown). 
TABLE 2: Effect of treatment with a mixture of nitrogen and phosphorus salts on dark-brown leaf spot blotch development and yield component (1000 Grains weight) for barley varieties (artificial infection, 2018, North-West region of Russian Federation).

\begin{tabular}{|c|c|c|c|c|c|}
\hline \multirow[t]{2}{*}{ Сорт } & \multicolumn{2}{|c|}{$\%$ of flag-leaf surface affected } & \multicolumn{2}{|c|}{1000 Grains weight, g } & \multirow[t]{2}{*}{ Increase \% } \\
\hline & Control & NP treatment & Control & NP treatment & \\
\hline Moskovskii 3 & 90 & 10 & 22.9 & 40.9 & 78 \\
\hline Zazerskii 85 & 90 & 10 & 19.9 & 36 & 81 \\
\hline Sonet & 90 & 25 & 25.3 & 37.7 & 49 \\
\hline Leningradskii & 90 & 30 & 24.8 & 31.1 & 26 \\
\hline Zenit & 90 & 30 & 33 & 41 & 23 \\
\hline Tausen & 90 & 30 & 37 & 42 & 13 \\
\hline Moskovskii 86 & 90 & 25 & 34.6 & 46.9 & 35 \\
\hline Chill & 90 & 25 & 29 & 42 & 47 \\
\hline Despina & 90 & 20 & 33 & 42 & 28 \\
\hline Izumrud & 90 & 30 & 32.4 & 37.4 & 15 \\
\hline Buian & 90 & 5 & 22.8 & 44.6 & 95 \\
\hline laromir & 90 & 25 & 31 & 37 & 21 \\
\hline Pamiati Rodinoi & 90 & 30 & 35.5 & 39.6 & 11 \\
\hline Kvench & 90 & 10 & 21.7 & 33.9 & 56 \\
\hline Brovar & 90 & 30 & 36.7 & 41.5 & 13 \\
\hline Eifel & 90 & 25 & 39.2 & 49.7 & 27 \\
\hline Pioner & 90 & 20 & 33.3 & 45.4 & 36 \\
\hline Eksploer & 90 & 30 & 38.9 & 44.6 & 14 \\
\hline Ceppelin & 90 & 20 & 33.8 & 43.6 & 29 \\
\hline Zhana & 90 & 5 & 21.9 & 45.5 & 108 \\
\hline Krasnoiaruzhskii 6 & 90 & 10 & 28 & 42 & 49 \\
\hline Olimpik & 90 & 15 & 24.1 & 38.8 & 61 \\
\hline Novik & 90 & 30 & 25.5 & 28.5 & 12 \\
\hline Overtiug & 90 & 5 & 21 & 44 & 108 \\
\hline Brennus & 90 & 25 & 29.6 & 37.2 & 26 \\
\hline Odissei & 90 & 25 & 36.5 & 47 & 29 \\
\hline Niagara & 90 & 20 & 36.4 & 50.2 & 38 \\
\hline Kangoo & 90 & 10 & 23.6 & 41.6 & 77 \\
\hline Volgogradskii 08 & 90 & 30 & 33.2 & 38.7 & 16 \\
\hline Volgogradskii 12 & 90 & 15 & 28 & 42 & 48 \\
\hline Krinichnyi & 90 & 30 & 37.6 & 42.4 & 13 \\
\hline Abava & 90 & 25 & 40.2 & 49.9 & 19 \\
\hline Cheerio & 90 & 30 & 36.4 & 42.9 & 15 \\
\hline Abalak & 90 & 20 & 32.1 & 42.7 & 25 \\
\hline Kal’kiul’ & 90 & 30 & 32.2 & 39.9 & 19 \\
\hline \multirow[t]{2}{*}{ Krasnoiarskii 91} & 90 & 25 & 30.5 & 36.7 & 16 \\
\hline & & & \multicolumn{2}{|c|}{$\mathrm{LSD}_{0.05}=3.1$} & \\
\hline
\end{tabular}




\section{Discussion}

The results of the conducted work confirm the earlier conclusion about the extremely narrow genetic diversity of barley from VIR Collection for effective resistance to darkbrown leaf spot blotch [4]: all 32 studied samples, described in recent times as sources for resistance to the disease [7, 8, 11], and 69 varieties, allowed being grown in the territory of the Russian Federation were highly susceptible to the disease both in seedling and adult stages.

This fact indicates urgent need in developing alternative method to grow resistant varieties for barley protection from dark-brown leaf spot blotch. Plants treatment with mixture of nitrogen and phosphorus salts solutions can be considered as one of these methods, at least for some barley varieties. In presented investigation, such treatment was significantly effective in the disease development decrease for 13 commercial varieties in the laboratory experiments on juvenile plants (from $100 \%$ of the disease development to $10--30 \%$ ) and for 36 varieties (52 \% out of all studied) in the field experiment on adult plants (from $90 \%$ to $5--30 \%$ ). For all these 36 varieties the disease development brought to significant increase in weight of barley seeds. The underlined mechanism of nitrogen and phosphorus salts effect allows assuming changing of salts concentrations and their ratio could broaden the range of varieties on which this treatment will decrease development of dark-brown leaf spot blotch.

\section{Conclusion}

Taking into account very limited reliable sources of effective resistance of barley to dark-brown leaf spot blotch; development of new methods to protect the crop from the disease is of high interest. The treatment of barley varieties plants with mixture of nitrogen and phosphorus salts has been shown to be effective method of reducing development of the disease as for seedlings as for adult plants. Comparing with fungicides applications this method is ecologically safe, much less expensive and theoretically must non result in changes of the pathogen population genetic structure. One of its main disadvantages was varietal specificity shown in our experiments: the used concentration of the salts was ineffective for 33 out of 69 studied varieties under field conditions. However the nature of the treatment effect to dark-brown leaf spot blotch decrease on barley plants allows suggesting the optimization of concentrations and ratios of the salts could lead to effective control of the disease on all varieties. Possibility of this optimization is still under study. 


\section{Funding}

The work was carried out within the framework of the State assignment according to the thematic plan of VIR for the theme № 0662-2019-0006 "Search, maintenance of viability and revealing of the hereditary variability potential in VIR world collection of cereal crops for development of optimized Gene bank and rational use in breeding and crop production ".

\section{Acknowledgement}

The authors would like to thank their colleague for their contribution and support to the research. They are also thankful to all the reviewers who gave their valuable inputs to the manuscript and helped in completing the paper.

\section{Conflict of Interest}

The authors have no conflict of interest to declare.

\section{References}

[1] Khasanov, B.A. (1992). Identifier of fungi -- casual agents of plant helminthosporiosis from genera Bipolaris, Drechslera и Exserohilum. Tashkent.

[2] Kumar, J., Schafer, P., Huckelhoven, R., Langen G. et al. (2002). Bipolaris sorokiniana, a cereal pathogen of global concern: cytological and molecular approaches towards better control. Molecular Plant Pathology, vol. 3, pp. 185--195.

[3] Steffenson, B.J., Hayes, P.M., Kleinhofs, A. (1996). Genetics of seedling and adult plant resistance to net blotch (Pyrenophora teres f. teres) and spot blotch (Cochliobolus sativus) in barley. Theoretical and Applied Genetics, vol. 92, pp. 552--558.

[4] Tyryshkin, L.G. (2007). Genetic variability of wheat and barley for effective resistance to diseases and possibilities of its broadening. PhD dissertation. Saint-Petersburg: VIR.

[5] João, A.W.F., Francisco, X.R.V., Ariano, M.P., Laércio, Z. (2005). Resistance of barley genotypes to brown leaf spot. Euphytica, vol. 142, pp. 217--225.

[6] Valjavec-Gratian, M., Steffenson, B.J. (1997). Pathotypes of Cochliobolus sativus on barley in North Dakota. Plant Diseases, vol. 81, pp 1275--1278. 
[7] Abdullaev, R.A., Batasheva, B.A., Radchenko, E.E. et al. (2017). Catalogue of the World collection of VIR: resistance of barley samples from Dagestan to harmful organisms and abiotic stresses. Saint-Petersburg: VIR.

[8] Orlov, S.Yu. (2014). Resistance of barley to Swedish fly (Oscinella frit L.) under conditions of the North-Western region of Russia. PhD dissertation. Saint-Petersburg: VIR.

[9] Afanasenko, O.S., Novozhilov K.V. (2009). Problems of rational use of genetic resources of plant resistance to diseases. Ecological genetics, vol. 7, pp. 38--43.

[10] Anisimova A.V., Abdullaev R.A. (2014). Screening of Dagestan barley for resistance to net and dark-brown leaf spot blotches. Proceedings on Applied Botany, Genetics and Breeding, vol. 175, pp. 67--71.

[11] Ivanova, N.V., Radiukevich, T.N., Anisimova A.V. (2010). Sources of economical biological characteristics of barley for breeding purposes. Saint-Petersburg: Belogorka.

[12] Lashina, N.M. (2015). Creation of barley dihaploids as an initial material for breeding varieties with group resistance to diseases. PhD dissertation. Saint-Petersburg: VIZR.

[13] Tyryshkin, L.G. (2016). Modification variability for virulence and aggressiveness in phytopathogens of cereal crops: conclusions, consequences, possibilities of practical application. Saint-Petersburg: SPbGAU.

[14] Fetch, T.Jr., Steffenson, B.J. (1997). Rating scales for assessing infection responses of barley infected with Cochliobolus sativus. Plant Disease, vol. 83, pp. 213--217.

[15] Arabi, M.I.E., Jawhar, M.J. (2010). A greenhouse method for assessing spot blotch resistance in barley. The Plant Pathology, vol. 26, pp. 421--423. 